\title{
Identifying sources of democratic legitimacy: A multilevel analysis
}

\author{
Min-hua Huang a,*, Yu-tzung Chang ${ }^{\text {a }}$, Yun-han Chu ${ }^{\text {a,b }}$

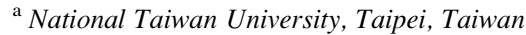 \\ ${ }^{\mathrm{b}}$ Academia Sinica, Taipei, Taiwan
}

\begin{abstract}
Democracy enjoys a significant base of popular support in the 41 country samples covered by CSES Module II. While higher levels of support for democracy seem to be a defining feature of the established democracy, the emerging democracies including post-communist regimes also enjoy a solid base of pro-democracy sentiment. The endurance of many emerging democracies is not under any immediate danger because popular belief in the superiority of democracy is not susceptible to the ups-and-downs of government performance or short-term economic fluctuation. Our analysis also demonstrates that all three theoretical perspectives, modernization/postmodernization, institution, and rationality, are indispensable for a comprehensive understanding of the sources of democratic legitimacy for both established and emerging democracies. However, most of the theoretical predictions based on a narrow conception of 'utility-maximization' turn out to be less relevant. Instead, our analysis shows that performance-based legitimacy is a function of a more diffuse basket of political goods including freedom, accountability and representativeness.
\end{abstract}

(c) 2007 Elsevier Ltd. All rights reserved.

Keywords: Democratic legitimacy; Satisfaction with democracy; Democratization

\section{Introduction}

For students of democratization, the question of how citizens evaluate their democratic regimes is of great significance (Linz and Stepan, 1996; Norris, 1999a; Putnam and Pharr, 2000). This is because negative evaluations or modest support for the newly established democratic regimes by its citizenry tend to erode support for democracy as an ideal. On the other hand, if citizens living under democratic regimes harbor highly positive and supportive attitudes for democracy, then the maintenance of

\footnotetext{
* Corresponding author. 21 Hsu Chow Road, Taipei, Taiwan 10020, ROC. Fax: +886-2-23412806.

E-mail address: mhhuang5103@ntu.edu.tw (M.-h. Huang).
}

democracy becomes easier (Diamond, 1999; Shin, 1999). Since the early 1990s, a series of cross-national survey research began to look at citizens of newly developing nations in Latin America, Africa, and Eastern Europe, focusing on popular evaluations of representative democracy and political participation. They include four regional barometer surveys, namely Latino Barometro, New Democracy Barometer, Asian Barometer and Afro Barometer, and Comparative Study of Electoral Systems (CSES), a study encompassing more than 50 countries across the globe. ${ }^{1}$

\footnotetext{
${ }^{1}$ For details on public opinion survey research dealing with democratization throughout the world, see Heath et al. (2005).
} 
The goal of this paper is to delineate and explain the systematic differences found between how citizens evaluate their democracies in established and developing democracies. Specifically, we focus on two attitudinal measures that are employed by CSES Module II: satisfaction with the way democracy works and belief in its superiority over other forms of government. Earlier research indicated that in established democracies the level of satisfaction was closely tied to economic performance, corruption, as well as trust in political institutions and political leaders. However, the citizens of established democracies would not doubt the legitimacy of democratic institutions even if they were dissatisfied with the performance of the incumbent government (Norris, 1999a; Putnam and Pharr, 2000). Yet, for some new emerging democratization studies, an adequate supply of a range of political goods, such as freedom, human rights, rule of law, fair treatment and popular accountability, is more important than the delivery of economic goods in shaping people's support for the democracy. Citizens expect and demand significant improvement in these areas when a political system becomes democratized (Bratton and Chang, 2006; Bishin et al., 2006; Whitefield and Evans, 1999).

Using hierarchical linear modeling, this paper identifies the foundation of legitimacy in established and emerging democracies under three theoretical perspectives: modernization/postmodernization, institutionalism, and rational choice theory. We controlled for institutional differences among countries such as presidentialism versus parliamentarianism, varying duration of liberal democracy, general economic indicators such as rates of unemployment and economic growth, and modernization indicators such as GDP per capita (purchasing power parity) and gender development indicator. Section 2 discusses a variety of methods for measuring democratic legitimacy and clarifies our own measurement strategy for accomplishing this task. Section 3 elaborates on a number of theories for the sources of support for democratic regime, including modernization theory, institutionalism, and rational choice theory. We would like to determine from our data which theoretical perspective exhibits a stronger explanatory power when they are tested against empirical data. Section 4 describes our research design as well as the steps we take to determine whether a nonlinear model or a hierarchical linear model is more appropriate for our purpose. Section 5 presents the main findings of our multilevel modeling. Finally, we conclude by explaining why we need a multi-faceted explanatory framework for a comprehensive understanding of the sources of democratic legitimacy for both established and emerging democracies.

\section{Gauging democratic legitimacy}

Put simply, democratic legitimacy comes from citizens believing that democracy can produce some 'good outcomes' (Anderson et al., 2005). However, legitimacy is a multifaceted concept, leading to a wide variety of definitions. As the first scholar to analyze the notion of 'democratic legitimacy,' David Easton classifies political legitimacy according to different legitimizing targets. These targets include the community, the regime, and authority. Any political system must evenly cultivate 'diffused support' and 'specific support' from members for the policies it makes and for its performance. The former comprises the socialization of members, patriotism, as well as trust and loyalty for the state. The latter is founded upon members acquiring some sort of particularistic compensation or benefits (Easton, 1965, 1975). Still, citizen support for the political system has many other targets and Easton's classificatory framework cannot fully capture the dimensions of political legitimacy (Weatherford, 1992). Consequently, Klingemann, Norris and Dalton and others have built upon the foundation of Easton's conceptual framework, broadening the targets of political legitimization into five types: political community, regime principle, regime performance, regime institutions, and political actors. Using this framework, they delved into a transnational, comparative analysis (Dalton, 1999; Norris, 1999a; Klingemann, 1999).

Yet, Morlin and Montero propose that one can gauge support for democratic regimes through three conceptual perspectives: diffuse legitimacy, legitimacy by default, and efficacy. 'Diffuse legitimacy' refers to absolute faith in the superiority of democratic institutions over other regime types, a form of legitimation that would not falter under any circumstance. 'Legitimacy by default' refers to intense rejection of the old regime by members of the political system and the desire to leverage the present democratic regime to change the status quo. As for efficacy, they are referring to the belief among members of a political system that democratic regimes can effectively solve complex social problems, resulting from members feeling satisfied by the performance of previous democratic regimes (Morlino and Montero, 1995, pp. 232-235).

Bratton and others also rely on citizen's preference for democracy and their rejection for non-democratic regimes such as militarism, authoritarianism, traditional rulers, or technocracy in order to conceptualize democratic legitimacy (Bratton et al., 2005, pp. 72-81; Bratton and Mattes, 2001). However, Rose, Shin, and others recognize that in addition to preference for democracy, 
one must also consider the desire for democracy and the suitability of democracy. The desire for democracy refers to the gap between the present level of democratic development and what citizens expect to see realized by the democratic regime; a high score indicates strong desire for democracy among the citizenry. What is called the suitability of democracy refers to the degree with which citizens feel that democracy is appropriate for their country; a high score suggests that the citizenry strongly believes that democracy is appropriate. Preference for democracy, desire for democracy, and suitability of democracy, constitute the set of indicators we use to gauge democratic idealism (Mishler and Rose, 2005; Shin and Wells, 2005).

To ground measurements of democratic legitimacy, this paper employs research data pertaining to satisfaction with democracy and preference for democracy from the CSES. Linde and Ekman point out that the use of 'satisfaction with democracy' to measure democratic legitimacy among citizens is not ideal because the indicator is only capable of measuring the actual performances of democracies, and because it is highly sensitive to variations in the time during which measurements are taken and to variations in political environments (Linde and Ekman, 2003). Consequently, this paper is concerned primarily with preference for democracy as an ideal. After all, this predisposition is more enduring and less susceptible to short-term political and economic stress and thus more critical to the resiliency of democracy. However, satisfaction with democracy is also of significance because over time it buttresses democratic legitimacy. On the other hand, protracted discontent with the performance of the democratic system will eventually erode popular support for democracy as an ideal (Putnam and Pharr, 2000).

In an ideal world, one should employ a battery of indicators to allow one to make valid statements about democratic legitimacy (Adcock and Collier, 2001, p. 538). In the CSES Module II, the preference for democracy is measured with a single item:

Please tell me how strongly you agree or disagree with the following statement: Democracy may have problems but it's better than any other form of government?

Despite this limitation, this item enjoys face validity because it explicitly addresses the superiority of democracy and helps us differentiate the influence of regime principles from that of performance. In principle, it is difficult to ascertain the true validity of any single-item measure, but we can confirm its validity indirectly. On one hand, we can test for 'discriminant validity,' provided that the two measures are not highly correlated with each other, as well as 'construct validity', if the explanatory sources of the two attitudinal measures differ sufficiently and in ways that meet theoretical prediction.

The data, collected from 38 countries and sampled between 2001 and 2006 under the auspices of CSES Module II, support our claim that the two measures are distinctively different. While the two measures, as one would expect, are positively correlated, their bivariate correlation coefficient (across all 41 country samples) suggests that the two are only weakly associated $(r=0.295)$. The strength of correlation also varies wildly, from as high as 0.476 (in Bulgaria) to as low and non-significant as -0.021 (in Albania). ${ }^{2}$ This means that the way the two measures correlate with each other varies from one historical context to another, suggesting that the underlying mechanisms are not the same.

In Fig. 1, we plot the 41 mean scores of the two measures on a two-dimensional space. On the macrolevel, the linear relationship between the two measures looks stronger $(r=0.677)$ than their bivariate correlation observed at the individual level. It is perhaps no coincidence that high levels of support for democracy as an ideal correlates with high levels of satisfaction with democracy in the so-called 'established democracies' or 'advanced industrial societies.' On the other hand, the combination of lower level of support for democracy as an ideal with a depressingly low level of satisfaction is found exclusively among societies that have experienced the trauma of the collapse of communism and transition from command economy and East Asian societies. This suggests that there are some macro-level forces at work in shaping the distribution of the two attitudinal predispositions. This observed pattern also calls for a cross-level analysis that helps decipher the causal mechanisms at both individual and macro-level.

\section{The sources of democratic legitimacy}

There are burgeoning efforts to apply sophisticated statistical modeling to cross-national survey data for winnowing out competing explanatory sources for the acquisition of belief in the legitimacy of democracy.

\footnotetext{
${ }^{2}$ Most of the country samples have a significant and positive correlation between 0.1 and 0.35 . Albania is the only case that has a negative but non-significant correlation.
} 


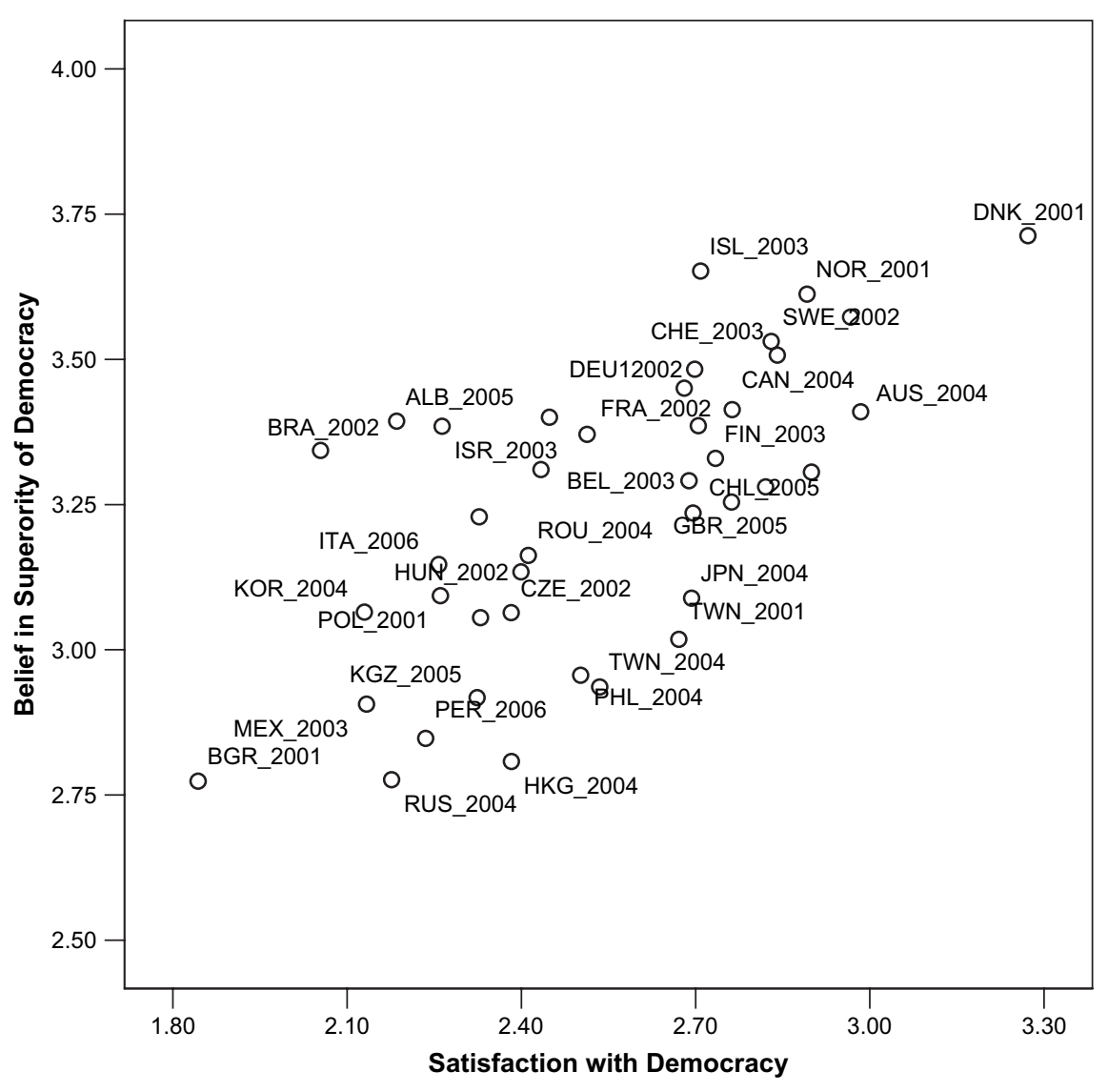

Fig. 1. Scatter plot of country mean scores of satisfaction with democracy and support for democracy.

However, most of the recent studies have focused on third-wave democracies (Rose et al., 1998; Rose and Mishler, 2003; Bratton and Mattes, 2003). With the exception of a few chapters in Pippa Norris's edited volume (Norris, 1999b), few scholars extend their comparative analysis to include both emerging democracies and established democracies. For example, in their initial efforts to tackle the question why people differ in their orientations toward democratic regime, Richard Rose, William Mishler and Christian Haerpfer (Rose et al., 1998, pp. 116-119) focused only on Central and Eastern European countries. Commonality in their trajectory of regime transition simplified the task of their comparative analysis but also precluded them from exploring the influence of certain system-level traits such as characteristics of 'ancient regimes' and modes of transition. Instead, they identified two competing theoretical perspectives: performance theories vs. socialization theories. According to Rose, Mishler and Haerpfer, socialization theories stress fundamental political values and believes formed through a lengthy process of socialization begun in childhood (Almond and Verba, 1963).
By contrast, performance theories hypothesize that individuals will support a form of government they believe to deliver more satisfactory outcomes than others (Rogowski, 1974). The performance criteria are often times defined in materialist terms, e.g., the ability to distribute economic benefits. Yet, performance can also refer to the delivery of political goods, such as the absence of political oppression, equal treatment, protection of political rights, and the responsiveness of leaders. They cautioned us, however, that the distinction between the two theoretical perspectives can be overdrawn. Both approaches conceive support for democracy vs. non-democratic forms of government as a product of experience. They differ principally in the time-frames and in the types of experiences that they regard as most relevant.

The dichotomy between the performance perspective and the socialization perspective was evidently not inclusive enough to cover a broad range of competing theoretical perspectives in comparative politics and at the same time left a huge room for theoretical refinement. More recently, Michael Bratton, Robert Mattes 
and E. Gyimah-Boadi (Bratton et al., 2005) have developed a more inclusive analytical framework in which they identified five theoretical traditions-sociological, cultural, institutional, cognitive, and rational-that might inspire competing hypotheses about how Africans acquired favorable orientations toward democracy. The rich data set from their Afrobarometer survey enabled them to evaluate the relevance of these competing theoretical perspectives in a unified model. And the diversity in the initial conditions of authoritarian breakdown among sub-Sahara countries that they examined also allow them to investigate the impact of some macro-level characteristics such as dominant post colonial regime type. ${ }^{3}$ However, they did not employ hierarchical linear models and missed the opportunity for a more rigorous cross-level multivariate analysis. In addition, the basic similarities in the macro-historical traits of sub-Sahara African countries still deprived them of meaningful cross-national variances.

While not being perfect, the data that was made available by CSES Module II possess many unique strengths. First, it cuts across both established democracies and emerging democracies. Second, it employs more revealing indicators about citizens' evaluation of the quality of democratic governance than the World Values Survey which is also cross-continental in scope. When combining the individual-level survey data collected under CSES Module II with relevant data on macro-level characteristics, we are in a strong position to examine an extensive array of relevant hypotheses, which can be grouped into at least three broad theoretical categories: modernization/postmodernization, institution, and rationality.

\subsection{Modernization and postmodernization}

Modernization theory has been developing over a century. The central claim of modernization theory from Karl Marx, Max Weber to Daniel Bell is that economic, cultural and political changes go together in coherent patterns that are changing in the world in predictable ways (Inglehart, 1997, p. 7). Modernization theory was understood by some as a variant of the structural explanation (Bratton and Mattes, 2003) because many modernization theorists emphasized social mobility and location in modern parts of the social structure as the leading cause of cultural change (Inkeles and Smith, 1974; Pye, 1990). While there has been

\footnotetext{
${ }^{3}$ They made the distinction among 'Settler Regime', 'Plebiscitary One-Party Regime, and 'Competitive One-Party Regime'.
}

continuing debate over the causal linkages, many empirical findings do support the claim that socioeconomic development generates more modern attitudes and values: greater tolerance and valuing of freedom, higher levels of political efficacy, greater capacity to participate in politics and civic life (Diamond, 1999). The postmodernization theory developed by Ronald Inglehart and his colleagues agree with the modernization theorists on their central claim but differ from most modernization theorists on four essential points: change is not linear; economic determinism is oversimplified; the rise of the West is not the only version of modernization; and democracy is not inherent in the modernization phase but democracy does become increasingly likely as societies move beyond the modernization phase into postmodernization (Inglehart, 1997, pp. 10-25).

Inglehart and his colleagues have accumulated three decades of time-series data with which to demonstrate an intergenerational shift toward postmaterialist values, linked with rising levels of economic development (Inglehart, 1977, 1997). As economic development brings rising levels of tolerance, trust, political activism, and greater emphasis on freedom of speech (the components of what they defined as 'self-expression values'), it leads to growing mass demands for liberalization in authoritarian societies, and to rising levels of direct mass participation in societies that are already democratic. In so far as postmaterialists give high priority to protecting freedom of speech and to participation in making important government decisions, this trend should bring growing mass demands for democracy. Following from the modernization/postmodernization perspective, one would predict that an intergenerational shift toward greater appreciation for democracy comes with the rapid expansion in education, vast improvements in economic wellbeing and increasing urbanization. Operationally speaking, at the macro-level we should expect to see a strong linear relationship between a country's level of socio-economic development and its aggregate level of support for democracy. At the micro-level we would predict that citizens with higher education and from younger generations would have a higher propensity to acquire favorable orientations toward democracy.

However, Inglehart (1999) has cautioned us that this cultural shift might generate rather different influences on citizens' evaluations of the performance of democracy. The post-modern shift to declining respect for and deference to authority among the publics of advanced industrial societies has contributed to dwindling 
confidence in political institutions and the growing number of citizens who are critical of the performance of the democracy. For an empirical testing of the modernization/postmodernization theses in our multivariate analyses, we focus on the impact of three socio-economic variables (urban residence, religious attendance and income), three demographic controlled variables (education, age and gender), at the individual level and two country-level socio-economic variables (GDP per capita and gender equality), on support for democracy as well as satisfaction with democracy. We hypothesize that the higher the modernization indicators, the stronger the level of support for democracy. But citizens with higher level of modernization characters might be more critical of and less satisfied with the performance of democracy.

\subsection{Institution}

A standard theoretical argument based on the neoinstitutionalist perspective would posit that people develop certain orientations toward democracy as well as non-democratic regimes as a consequence of the organizing principles of formal and informal institutions: specifically, the incentives, disincentives and habits created by the rules embedded in differing forms of political institutions (Steinmo et al., 1992; Hall and Taylor, 1996; Muller and Seligson, 1994; Norris, 1999a; Bratton and Mattes, 2003). Participation in formal procedures like voting, working for parties or candidates, attending election rallies, attending community meetings, joining with others to raise issues or contacting elected leaders can have an educative effect increasing interest and efficacy (Finkel, 1987) as well as building support for democracy (Bratton et al., 1999; Finkel et al., 2000). In turn, affiliations with political parties help citizens to relate to the political system and strengthen their identification with democracy. Also, membership in civic organizations may shape social capital and build up the cooperative practices and organizational and communicative skills that individuals can apply in other and larger political arenas (Nie et al., 1969; Putnam, 1993; Brady et al., 1995; McDonough et al., 1998; Shin, 1999). The historical institutionalist perspective, in particular, emphasizes the socializing effects of institutions in shaping citizens' preferences or even identity over time (Steinmo et al., 1992). Practicing democracy over time would help citizens develop a new and longer term perspective on judging democracy, based on an appreciation of the intrinsic nature of democracy rather than its consequences.
A recent debate sparked by Juan Linz's seminal work on the perils of presidentialism in Latin America (1990) focuses on the effects of presidentialism and parliamentary government on democratic stability (Linz and Valenzuela, 1994; Mainwaring, 1993; Stepan and Skach, 1993; Power and Gasiorowski, 1997; Mainwaring and Shugart, 1997). On the basis of a statistical analysis of 135 countries observed annually between 1950 and 1990, Adam Przeworski and his associates concluded that 'Parliamentary regimes last longer, much longer, than presidential ones ...' (Przeworski et al., 1996, p. 47). The reason that presidentialism is not conducive to democratic stability is manifold. As Juan Linz explicated, presidentialism exhibits a number of features that contribute to political conflict and instability, notably the separation of powers between the executive and the legislative, both of which are elected by the citizens. In political confrontations, each branch claims to represent the people, and each develops a rigid position. Regime crisis may ensue, because no easy mechanisms exist to replace presidents who have lost the confidence of the legislature. Presidential systems also contribute to the decline of political parties, the key institution for political representation in modern democracies. Presidential systems, especially those with doubleround elections, stimulate fragmented party systems, the dangers of which have been amply analyzed by Giovanni Sartori (1976).

However, the effects of institutional designs on the development of popular support for democracy have not been thoroughly investigated so far. In their recent work on South Korean democracy, Diamond and Shin (2000) argued that presidentialism is partially responsible for the superficial and fragmented nature of South Koreans' support for democracy. The 39 country samples (Hong Kong and Kyrgyzstan excluded) examined in this paper cover a full range of constitutional design, from parliamentary systems, to parliamentary systems with a popularly elected president, to semi-presidentialism to presidentialism. It is interesting to see if political institutions with a stronger tendency towards presidentialism have higher attenuating effects on support for as well as satisfaction with democracy.

For an empirical testing of the institutionalist thesis in multivariate analyses, we focus on the impact of the following individual-level variables - index of electoral participation, index of non-electoral participation (primarily citizen-initiated contact), partisan orientation toward the winner, and partisan attachment-plus two country-level variables-life-span of democracy and type of political institution-on support for as 
well as satisfaction with democracy. We hypothesize that both higher political participation and stronger partisan affiliation may bring about stronger support for democracy. Also, we hypothesize that the longer the learning experiences under a democracy the stronger the propensity to believe in democratic legitimacy. However, the causal mechanisms identified above are not expected to be working for satisfaction with the way democracy works. Lastly, we hypothesize that experiences with presidentialism, and to some extent semi-presidentialism, will tend to erode support for democracy as an ideal.

\subsection{Rationality}

Rational choice theorists believe that citizens support democratic regimes because the performance of the current democratic regime appears superior to that of previous authoritarian regimes in areas such as rule of law, the advancement or protection of individual rights and social welfare, and responsiveness to public opinion (Evans and Whitefield, 1995; Whitefield and Evans, 1999). Furthermore, rational choice theory can be extended in two ways to explain why citizens of third-wave democratic states would turn away from authoritarianism and embrace democracy.

The first type of explanation is built upon the foundations of classical rational choice theory. This explanation focuses particularly on underdeveloped and poor countries, asserting that citizens generally hope democratic governments can first develop the economy and satisfy humanity's basic material needs. On the other hand, one can postpone discussion of post-material needs for the future (Inglehart, 1997). Researching experiences of political transition in Eastern and Central Europe, Kitschelt also discovered that of the many factors that influence citizens' support democracy, perceptions of change in individual or national economic circumstances is the most important one (Kitschelt, 1992). Writing about how citizens respond to and form attitudes about democratic transition, Przeworski similarly points out the most relevant factor is the gap between subjective expectations and real economic experiences (Przeworski, 1991, p. 184). Consequently, if citizens believe democracy can improve their personal economic circumstances and that of the nation, then the potential for popular support for democracy increases. If high unemployment rates and high levels of inflation frequently accompany democratization, the probability that citizens would support democracy will decrease. According to recent studies, democracies indeed outperform authoritarian states on many economic development indices, such as population control, rise in per capital income, and the reduction of wealth inequality (Przeworski et al., 2000; Halperin et al., 2004). On the other hand, others point out that the benefits associated with democracy are enjoyed largely by middle and upper classes, providing the poor with little if any benefits (Ross, 2006).

Involving a broader interpretation of rational choice theory, the other type of explanation sees standards of human rationality and judgment becoming more relevant. In this view, not only do citizens compare the economic performances of different political systems, they also compare the production of political goods. The latter is associated with the quality of democratic governance and is more important that the former (Bratton et al., 2005). Because citizens are able to recognize the difference between support for democracy and support for government, they would not place the blame for their economic discontent on democratic governance (Schmitter, 1994; Waldron-Moore, 1999). However, the subjective evaluation of the quality of democratic governance, including the maintenance of political order, the defense of human rights, freedom of association, corruption, trust for democratic institutions, and the performance of the democracy, or personal feelings over the responsiveness of democracy to their needs, are all important determinants in the rationality of citizens when they evaluate their support for democracy. These assertions have already been validated through the democratization experiences of some Eastern European and African countries (Evans and Whitefield, 1995; Whitefield and Evans, 1999).

For an empirical testing of the utilitarian theses based on the provision of political goods, we focus on the impact of the following variables: satisfied with the way democracy works, perceived level of political corruption, perceived level of individual freedom, perceived effectiveness of popular accountability through voting, and perceived representativeness of the system, as well as whether citizens felt that they are being adequately represented by a particular party or a particular candidate in the political system-on support for and satisfaction with democracy. Also, we include two variables measuring citizen's evaluation toward the per formance of the current government, government performance on general issues (labelled as 'general performance') and government performance of on the most important issue (labelled as 'specific performance'). We hypothesize that perceived effectiveness in delivering a high standard of democratic governance contributes to both stronger support for democracy and more satisfaction with democracy.

In the following, we test these competing hypotheses against a comprehensive data set made available by the 
38 country teams that implemented the CSES Module II between 2001 and 2006.

\section{Research design and model specification}

The aim of our research design is to tackle three questions: First, what factors account for citizens' satisfaction with democracy? Second, what factors contribute to the growth of popular belief in the superiority of democracy? Third, is there any significant heterogeneity of the previous findings for support of democracy across different countries? If yes, what system-level traits explain the cross-national divergence? To achieve these analytical purposes, we adopt ordinal regression model for the first two questions with Mplus 4.2 and hierarchical linear models for the last one with HLM 6.0.

Our individual-level data all come from the CSES Module II. This dataset includes 41 country samples administrated by three different survey methods: mail-back, telephone or face-to-face interview. Each country sample is collected after a national election, except for Germany having two samples with different survey methods in 2002. ${ }^{4}$ Therefore, we combine the two German samples to form one country sample and weight each country sample equally in our analysis by adopting sampling weights. ${ }^{5}$ For the sake of multilevel inference, Hong Kong and Kyrgyzstan are not included since they are not democracies.

With regard to the objective country-level data, we include the following six macro variables: 'type of government', 'democratic lifespan', 'unemployment', 'economic growth', 'GDP per capita', and 'gender equality'. Except for 'type of government', which is coded by our own judgment, ${ }^{6}$ all the data come from various sources,

\footnotetext{
${ }^{4}$ Portugal and Taiwan also has two samples, but they were collected at different times (2002, 2005 for Portugal and 2001, 2004 for Taiwan). We treated them as two different country samples and weighted equally as others.

5 For instance, if $N$ is the size of all 38 country samples, each country will be weighted to $1 / 38$. That means for a country with the sample size $n$, the sampling weights for this country sample is $N / 38 n$.

${ }^{6}$ We adopt the categorization developed by Shugart and Carey (1992) to code 'type of government' as a four-rank Likert variable, ranging from parliamentarianism to presidentialism. The specific coding of each country sample is listed as follow: parliamentarianism coded as 0 includes Albania, Australia, Belgium, Canada, Czech Republic, Denmark, Germany, Hungary, Israel, Italy, Japan, Netherlands, New Zealand, Norway, Spain, Sweden, Switzerland, and United Kingdom; premier presidentialism coded as 1 includes Bulgaria, Finland, Iceland, Ireland, Poland, and Portugal, Romania, Slovenia, president-parliamentarianism coded as 2 includes Taiwan, France, Russia, and South Korea; presidentialism coded as 3 includes Brazil, Chile, Mexico, Peru, Philippines, and United States.
}

including Polity IV and World Development Indicators, CIA World Factbook, and Human Development Report.

The dependent variables for the first and latter two questions mentioned earlier are 'satisfaction with democracy' and 'belief in superiority of democracy', respectively.' Both are measured with a four-point Likert scale. While it is obvious that the ordinal logistic model is more appropriate for a Likert-type dependent variable, we decide applying it only in the first two questions but not the last. The main reason is that the weighting option is not available for the ordinal logistic model in HLM 6. Therefore, we apply a hierarchical linear model instead of a nonlinear one, in which the dependent variable is treated as interval rather than ordinal and allows the weighting option. ${ }^{8}$ However, unweighted ordinal logistic and weighted linear models are also presented to see whether assuming the linearity of the dependent variable or violating equalweight assumption of each country sample will significantly change our regression results.

The explanatory variables are organized as four groups: modernization/postmodernization, institution, rationality, and demographic controlled variables, standing for the three theoretical explanations discussed in the previous section. Taken together, we include 19 individual-level and six country-level variables in total. The detail about the variable formation and the re-coding scheme can be found in Appendix A.

It is no wonder that all of the variables have a varying proportion of missing cases. This leads to a serious problem if we want to include all of the 18 independent variables in the regressions by the listwise method. ${ }^{9}$

\footnotetext{
7 'Satisfaction with democracy' is treated as the dependent variable in our first question, but it is taken as an explanatory variable in the other two questions. The rationale behind this design is that we believe whether people satisfy with how democracy works is a strong intermediate variable to account for people's belief in superiority of democracy. Investigating why people satisfy or dissatisfy with democracy is very meaningful to our understanding of democracy, especially comparing with the analysis of people's belief in superiority of democracy.

${ }^{8}$ HLM 6.0 allows weighting for a continuous dependent variable, but not an ordinal one. If the method of multilevel logistic regression is adopted, we will violate the equal-weight assumption since each country sample has a different sample size; otherwise, we have to assume linearity of the dependent variable if the method of multilevel linear regression is implemented. Based on the result of Table 2 presented later in the main text, assuming the linearity assumption doesn't make much difference when we analyze the individual-level model on 'belief in superiority of democracy', although it is difficult to say whether the linearity assumption or the equal-weight assumption will bias our estimation more in the multi-level modeling.

${ }^{9}$ Only $21.1 \%(13,574 / 64,256)$ of the total observations remain if the listwise method is applied.
} 
Moreover, multilevel analysis is more demanding in terms of data quality since a country sample will be excluded if it has one or more variables that are completely missing. To cope with this problem, we conduct multiple imputations with the STATA function of ice and set the number of imputations as 25 . No imputation is done for the two dependent variables, but we still have $83.4 \%(53,585 / 64,256)$ of the total observations after multiple imputations if the listwise method is applied.

It is usually recommended that researchers should have a clear theoretical framework in mind when they conduct multilevel modeling. Most importantly, each model specification should follow a consistent rationale instead of arbitrary manipulation. In our analysis, we are interested in the question what factors explain people's belief in superiority of democracy and whether different countries have heterogeneous explanations. The best way to tackle both questions is to adopt a "random coefficient model" and we can tell whether a factor explains by the significance of the beta coefficient and also evaluate the heterogeneity of individual-level findings with chi-square tests of variance components. In order to keep the model parsimonious and intelligible, we specify the full HLM model with a macro-level predictor only when the random coefficient is significant and shows great variance.

The reason for restricting one contextual variable is that HLM 6.0 has estimate problems of robust standard errors if more than one contextual variable is added into the model. Furthermore, we are aware that it is impossible to exhaust all the possibilities of model specification in the macro-level model. Therefore, we choose to find out a coherent explanation by interpreting all the results meaningfully when adding different contextual variables. We do not pursue a 'best' finding simply by optimizing the modelfit statistic.

The result of our hierarchical linear modeling will distinguish three different relationships, that is, individual-level effects, country-level contextual effects, and country-level crossover effects. We expect little change in the individual-level effects no matter what contextual variable is brought in. If so, it indicates that our findings are not sensitive to different specifications of the macrolevel model. On the other hand, we do expect to see some changes in both country-level effects. Contextual effect indicates a direct influence of the social environment to a person's attitude. Crossover effect signifies the existence of the heterogeneous individual-level relationship which can be systematically explained by a macro variable. Having the three types of findings, we can derive a full picture of why people believe in the superiority of democracy.

\section{Results}

Corresponding to the three questions previously mentioned, we present the findings in the same order. As can be seen in Models I and II of Table 1, we find all of the three theories to a varying degree can explain people's satisfaction with democracy and belief in superiority of democracy. In terms of satisfaction with democracy as Model I shows, the rationality perspective has the strongest explanatory power since most of the standardized beta-coefficients are apparently higher than the other groups of variables. Within the rationality groups of variables, all indicate that the more positive the people's evaluation toward quality of governance,

Table 1

The factors related to the satisfaction with democracy and belief in superiority of democracy

\begin{tabular}{|c|c|c|}
\hline Explanatory variables & $\begin{array}{l}\text { Model I. } \\
\text { Satisfaction }\end{array}$ & $\begin{array}{l}\text { Model II. } \\
\text { Belief }\end{array}$ \\
\hline \multicolumn{3}{|c|}{ I. Modernization/postmodernization } \\
\hline Urban residence & $-0.015^{* * *}$ & $0.010^{*}$ \\
\hline Religious attendance & $0.008^{*}$ & -0.006 \\
\hline Income & $0.010^{*}$ & $0.038^{* * *}$ \\
\hline \multicolumn{3}{|l|}{ II. Institution } \\
\hline Electoral participation & 0.003 & $0.021^{* * *}$ \\
\hline Non-electoral participation & $-0.013^{* *}$ & $0.076^{* * *}$ \\
\hline $\begin{array}{l}\text { Partisan orientation } \\
\text { toward the winner }\end{array}$ & $0.032^{* * *}$ & $0.013^{* *}$ \\
\hline Partisan attachment & 0.004 & $0.065^{* * *}$ \\
\hline \multicolumn{3}{|l|}{ III. Rationality } \\
\hline Accountability & $0.025^{* * *}$ & $0.108^{* * *}$ \\
\hline Representation system & $0.124^{* * *}$ & -0.005 \\
\hline $\begin{array}{l}\text { Representation parties } \\
\quad \text { or candidates }\end{array}$ & $0.057^{* * *}$ & $0.066^{* * *}$ \\
\hline Freedom & $0.248^{* * *}$ & $0.098^{* * *}$ \\
\hline Corruption & $-0.144^{* * *}$ & $-0.054^{* * *}$ \\
\hline General performance & $0.206^{* * *}$ & $0.017^{* *}$ \\
\hline Specific performance & $0.094^{* * *}$ & $-0.017^{* *}$ \\
\hline Satisfaction with democracy & - & $0.210^{* * *}$ \\
\hline \multicolumn{3}{|c|}{ IV. Demographic controlled variables } \\
\hline Education & $0.030^{* * *}$ & $0.104^{* * *}$ \\
\hline Gender & -0.004 & $-0.009^{*}$ \\
\hline Age & $0.011^{* *}$ & $0.061^{* * *}$ \\
\hline \multicolumn{3}{|l|}{ Constant } \\
\hline Threshold 1 & $0.850^{* * *}$ & $0.225^{* * *}$ \\
\hline Threshold 2 & $1.912^{* * *}$ & $1.151^{* * *}$ \\
\hline Threshold 3 & $3.411^{* * *}$ & $2.576^{* * *}$ \\
\hline$R$-squared & 0.325 & 0.184 \\
\hline$N$ & 59526 & 55379 \\
\hline
\end{tabular}

Note: Entry is standardized coefficient. Significance level: ${ }^{*} p \leqq 0.05$; ${ }^{* *} p \leqq 0.01 ;{ }^{* * *} p \leqq 0.001$. Program: Mplus 4.2. 
the more the satisfaction with democracy. Moreover, among the factors that explain, perceived level of individual freedom, government performance on general issues, perceived representativeness of the electoral system, and perceived level of corruption are more influential than government performance on the most important issue, perceived representativeness of the party or candidate, and perceived effectiveness of popular accountability. This finding implies that the general evaluation of substantial political goods largely decides whether people are satisfied with democracy rather than the sense of political efficacy.

The explanatory power that follows next is the modernization/postmodernization perspective, in which all of the three predictors are significant but obviously less powerful than the rationalist's explanation. We found that people living in urban areas are much more critical and less satisfied with how democracy works, but those who are more religious and have higher income tend to be more satisfied. The above findings suggest that modernization exerts two different mechanisms to influence people's satisfaction with democracy. On one hand, the phenomenon of critical democrats is more and more salient when modernity continues driving urbanization and secularization away from traditional society; on the other hand, once people go through the modernization process themselves, they will gradually acknowledge democracy as a fundamental social value in a modern world and therefore are more positive about it. This inference can be corroborated from the significant relationship that better educated people are more satisfied with democracy.

With regard to the institutionalist explanation, the findings reflect two interesting facts. For those who participate more in citizen-initiative political activities, they are usually less satisfied with democracy since the motive behind their non-electoral participation has already reflected in their actions, usually related to petition, demonstration, or protest again the government. Nevertheless, people are more willing to give positive evaluation toward democracy if the incumbent government was their political choice. For people in a democracy, it is no wonder that favorable opinions toward the government is in the eye of the beholder.

Shifting the focus to the results related to 'belief in superiority of democracy' in Model II, we find a remarkable change of the relative explanatory power for the three theories if 'satisfaction with democracy' is added as a control variable. Apparently, both modernization/postmodernization and institution perspectives have played a more significant role to account for belief in superiority of democracy, and meanwhile the explanatory power of the four most influential variables in rationalist account is largely weakened. Moreover, perceived effectiveness of popular accountability, which is the least influential factor explaining satisfaction with democracy in rationalist account, now becomes the most powerful factor to explain why people believe in superiority of democracy. All of the above findings display a sharp contrast of the logic underneath people's belief in superiority of democracy as opposed to that underneath their satisfaction toward democracy, and it can be summarized as the following four conclusions. First, there is no phenomenon of critical democrats accounting for belief in democracy since neither urban residence or religious attendance explains as it should in Model I. Second, going through the modernization process as being better educated, living in urban areas, or having more income will greatly strengthen people's belief in the superiority of democracy. Third, all of the institutionalist's predictors have strong explanatory power and that indicates behavioral or psychological input is indeed an important driving force to establish the social value of democracy. Interestingly, while those whose political choice is the winner are still more likely to acknowledge the superiority of democracy, such an effect is relatively less influential than it is on the satisfaction with democracy. It shows people are more idealistic and less utilitarian where belief in democracy is concerned. Finally, the ups and downs of the explanatory power for rationality predictors from Model I to II also confirms that people are more idealistic about democracy as a better political system. It is equally important for the delivery of substantial political goods as well as their political efficacy such as perceived representativeness of the party or candidate and perceived effectiveness of popular accountability. ${ }^{10}$

A drawback of using multi-national pooled data is that we may fall into the ecological fallacy if we do not purge out the contextual effect from the individual-level relationship. The precondition of this possibility is that the dependent variable has significant variance from the between-country variation. Our ANOVA analysis does corroborate this precondition and indicates that our data should be treated as hierarchical and we may find

\footnotetext{
10 The negative relationship between government performance on the most important issue and belief in superiority of democracy is against our expectation. However, as our finding shows in Tables 2 and 3, this relationship is spurious and it will disappear once we separate within-country variation from between-country variation.
} 
Table 2

Three random coefficient models for belief in superiority of democracy

\begin{tabular}{|c|c|c|c|c|}
\hline Explanatory variables & $\begin{array}{l}\text { Model III. Unweighted } \\
\text { ordinal logistic }\end{array}$ & $\begin{array}{l}\text { Model IV. Unweighted } \\
\text { linear }\end{array}$ & $\begin{array}{l}\text { Model V. weighted } \\
\text { linear }\end{array}$ & $\begin{array}{l}\text { Significant } \\
\text { heterogeneity }\end{array}$ \\
\hline \multicolumn{5}{|l|}{ I. Modernization/postmodernization } \\
\hline Urban residence & $2.741^{* *}$ & $2.184^{*}$ & 1.791 & $\mathrm{~N}$ \\
\hline Religious attendance & 0.744 & 0.335 & 0.381 & $\mathrm{~N}$ \\
\hline Income & $5.935^{* * *}$ & $5.222^{* * *}$ & $5.004^{* * *}$ & Y (specified) \\
\hline \multicolumn{5}{|l|}{ II. Institution } \\
\hline Electoral participation & $4.487^{* * *}$ & $4.777^{* * *}$ & $3.952^{* * *}$ & $\mathrm{~N}$ \\
\hline Non-electoral participation & $7.932 * * *$ & $6.725^{* * *}$ & $6.440^{* * *}$ & $\mathrm{~N}$ \\
\hline Partisan orientation toward the winner & 1.011 & 1.486 & 1.596 & $\mathrm{Y}$ \\
\hline Partisan attachment & $5.484^{* * *}$ & $5.039^{* * *}$ & $4.938^{* * *}$ & Y (specified) \\
\hline \multicolumn{5}{|l|}{ III. Rationality } \\
\hline Accountability & $10.779^{* * *}$ & $10.050^{* * *}$ & $10.780^{* * *}$ & Y (specified) \\
\hline Representation system & -0.788 & 0.223 & 0.938 & $\mathrm{Y}$ \\
\hline Representation parties or candidates & $3.856^{* * *}$ & $3.891^{* * *}$ & $3.062^{* *}$ & Y (specified) \\
\hline Freedom & $10.528^{* * *}$ & $10.857^{* * *}$ & $10.007^{* * *}$ & Y (specified) \\
\hline Corruption & 0.285 & 0.670 & 0.789 & $\mathrm{Y}$ \\
\hline General performance & $3.647^{* * *}$ & $3.618^{* * *}$ & $3.583^{* * *}$ & Y (specified) \\
\hline Specific performance & -1.854 & -1.263 & -1.219 & $\mathrm{~N}$ \\
\hline Satisfaction with democracy & $13.869^{* * *}$ & $13.339^{* * *}$ & $12.767^{* * *}$ & Y (specified) \\
\hline \multicolumn{5}{|l|}{ IV. Demographic controlled variables } \\
\hline Education & $16.029^{* * *}$ & $15.210^{* * *}$ & $14.409^{* * *}$ & \\
\hline Gender & $-3.994^{* * *}$ & $-3.009^{* *}$ & $-2.373^{*}$ & \\
\hline Age & $5.814^{* * *}$ & $5.248^{* * *}$ & $4.395^{* * *}$ & \\
\hline \multicolumn{5}{|l|}{ Constant } \\
\hline Threshold 1/intercept & $-3.604^{* * *}$ & $81.711^{* * *}$ & $82.629^{* * *}$ & Y (specified) \\
\hline Threshold 2/d(2) & $25.188^{* * *}$ & $\mathrm{Na}$ & $\mathrm{Na}$ & \\
\hline Threshold 3/d(3) & $22.466^{* * *}$ & $\mathrm{Na}$ & $\mathrm{Na}$ & \\
\hline Deviance & $\mathrm{Na}$ & 99815 & 95951 & \\
\hline$N$ & 53585 & 53585 & 53585 & \\
\hline
\end{tabular}

Note: Entry is $t$-value. Significant heterogeneity refers to both chi-square tests of variance component in Models III and IV, significant at the level of $p \leqq 0.001$. A macro predictor is specified to explain a random coefficient only if it has explanatory power and shows significant heterogeneity. It is marked 'specified' in the column of 'Significant heterogeneity'. Significance level: ${ }^{*} p \leqq 0.05 ;{ }^{* *} p \leqq 0.01 ;{ }^{* * *} p \leqq 0.001$. Program: HLM 6.0.

heterogeneous relationships across different countries. ${ }^{11}$ In order to find out which individual-level relationship has great heterogeneity across different countries, we need to conduct random coefficient modeling to provide us with information and appropriate judgments.

The statistics presented in Table 2 are the $t$-values of the regression coefficients of all the individual-level variables, and we simplify the presentation of chi-square tests by marking $\mathrm{Y}$ if a predictor has a significant variance component for both Models IV and V. ${ }^{12}$ Otherwise, we mark N to indicate not specifying a macro-level predictor to explain the variance component. All of the independent variables are specified as random coefficients. By comparing the models of the 'unweighted ordinal logistic' (Model

\footnotetext{
11 Our ANOVA shows that the random effect of the country means has a chi-square value of $6960(\mathrm{df}=38)$, for which the $p$-value is 0 . 000 .

12 The criterion of the significance level for the chi-square test is below 0.001 .
}

III), 'unweighted linear' (Model IV), and 'weighted linear' (Model V), we can easily identify what variables have robust relationships with belief in the superiority of democracy, regardless of the weighting or linearity assumption. The result indicates that most of the individuallevel relationships remain the same and are not affected by either the weighting or linearity assumption. The only exception is the beta-coefficient of 'urban residence' which just falls short of the significance level and is subject to the weighting assumption. We therefore believe making either assumption will not threaten our inference and decide to accept the linearity assumption and apply hierarchical linear modeling with the weighting function as shown in Model IV.

Comparing the regression results presented in Table 2 with those in Model II of Table 1, we can find three inconsistent findings for the variables of 'partisan orientation toward the winner', "perceived level of corruption', and 'government performance on the most important issue'. All of the three are significant predictors in the pooled-data analysis but found not significant if they 
are centered with the group means and specified as random coefficients. Apparently, the pseudo individual-level relationship might have been wrongly concluded when we conflated the effects of within- and between-country variations in Model II. And such non-significant results suggest that these predictors do not have explanatory power by themselves. In order to keep our HLM model as simple as possible, we do not specify a macro explanatory variable to explain the variance component of these predictors, even though these variables might still have explanatory power under certain macro conditions. ${ }^{13}$

According to the chi-square tests of variance components in Models III and IV,${ }^{14}$ we find at least eleven beta coefficients need a macro-level predictor to explain across different countries as those marked with ' $\mathrm{Y}$ ' in Table 2. ${ }^{15}$ However, among those coefficients which show significant heterogeneity across different countries, only eight of them are significant and deserve more explanation on what macro-level factors cause the cross-national divergence of findings. In sum, all beta coefficients are specified as randomly varied for the full HLM model, but we only attempt to explain the heterogeneity for those significant beta coefficients in the individual-level model.

With the above findings, we conduct hierarchical linear modeling by adding one macro-level predictor at a time. The way to report our findings follows the order from individual-level relationships, contextual effects, to crossover effects. The purpose is to examine what and how country-level factors influence people's belief in the superiority of democracy and changes individual-level relationships systematically under different circumstances. The overall results will give us a full picture to account for the heterogeneity of the individual-level relationship cross-nationally.

\footnotetext{
13 If an individual-level predictor loses its explanatory power when we apply random coefficient modeling instead of pooled-data analysis, it means that no individual-level relationship can be concluded unless we consider the possibility that certain macro-level factors result in such a non-significant finding. While it is very interesting to delve into all kinds of possibility that explain its non-significance and hence might derive an inference about under what conditions a significant result can be concluded, this attempt is beyond the scope of this article. Here, we want to caution the reader that a non-significant individual-level finding under random coefficient modeling only means it is not significant if no macro-level explanation is considered. And for the sake of parsimony, we decide not to specify a macro-level predictor for a non-significant coefficient.

${ }^{14}$ HLM 6.0 only performs the test of variance components for unweighted models.

15 Here, we decide not to specify demographic controlled variables with a macro-level predictor based on the parsimonious principle to keep the model as simple as possible.
}

As Table 3 shows, we start to examine the individuallevel relationships when the level of the country variables is holding at the middle level. For the clarity of presentation, we do not report non-significant coefficients and replace them with a dash. Generally, the results from Models VI-XI all confirm the same findings as seen in our random coefficient model (Model V) in Table 2. Those who do have a stronger belief in superiority of democracy are more likely to be the citizens who have a higher level of income and education, participate more frequently in electoral or non-electoral activities as well as have stronger partisan attachment, and give positive evaluation towards the perceived effectiveness of popular accountability, representativeness of the party or candidate, perceived level of individual freedom, government performance on the most important issue, and how satisfactory democracy works. The theoretical perspectives of modernization/ postmodernization, institutionalism, and rational choice explanations are all indispensable and contribute to a comprehensive understanding on the source of democratic legitimacy from cross-national evidence.

Next, we are interested in how a macro predictor can explain contextual effects, which refers to a direct influence of the country-level characteristic on individuallevel baseline for different countries. As can be seen from Models VI-XI, among the six country-level variables, the four macro-level variables selected from the institution and modernization/postmodernization all show significant and expected contextual effects, but not the two rationality macro-level variables. Specifically we find if the country has a political system closer to parliamentarianism, a longer lifespan of democracy, or a higher level of GDP per capita or gender equality, people have stronger belief in the superiority of democracy on average. ${ }^{16}$ On the other hand, short-term fluctuations of socio-economic conditions such as unemployment or lower economic growth do not attenuate people belief in democracy whatsoever. ${ }^{17}$ Democracy is

\footnotetext{
${ }_{16}$ Most of the well-established democracies adopt parliamentarianism except the United States.

17 While economic growth does have a significant but inversed contextual effect on belief in superiority of democracy, we suspect this finding is driven by the fact that most of the well-established democracies have a small or even negative growth rate as opposed to the high growth rate in those emerging democracies. It is no wonder that people in a well-established democracy (also in the context of little economic growth) have stronger belief in superiority of democracy. Their support of democracy does not count on fast economic growth.
} 
Table 3

The hierarchical linear model for belief in democracy

\begin{tabular}{|c|c|c|c|c|c|c|}
\hline \multirow[t]{2}{*}{ Explanatory variables } & \multicolumn{6}{|c|}{ Model (level-2 variable) } \\
\hline & $\begin{array}{l}\text { VI. Type of } \\
\text { Government }\end{array}$ & $\begin{array}{l}\text { VII. Democratic } \\
\text { Lifespan }\end{array}$ & $\begin{array}{l}\text { VIII. } \\
\text { Unemployment }\end{array}$ & IX. Growth & $\begin{array}{l}\text { X. GDP } \\
\text { per capita }\end{array}$ & $\begin{array}{l}\text { XI. Gender } \\
\text { Equality }\end{array}$ \\
\hline \multicolumn{7}{|l|}{ I. Modernization/postmodernization } \\
\hline Urban residence & - & - & - & - & - & - \\
\hline Religious attendance & - & - & - & - & - & - \\
\hline Income & $0.009^{*}$ & $0.038^{* * *}$ & $0.018^{* * *}$ & $0.018^{* * *}$ & $0.018^{* * *}$ & $0.018^{* * *}$ \\
\hline Level-2 variable & $0.009^{* *}$ & $-0.001^{* * *}$ & - & - & - & $-0.151^{*}$ \\
\hline \multicolumn{7}{|l|}{ II. Institution } \\
\hline Electoral participation & $0.008^{* * *}$ & $0.008^{* * *}$ & $0.008^{* * *}$ & $0.008^{* * *}$ & $0.008^{* * *}$ & $0.008^{* * *}$ \\
\hline Non-electoral participation & $0.030^{* * *}$ & $0.030^{* * *}$ & $0.030^{* * *}$ & $0.030^{* * *}$ & $0.030^{* * *}$ & $0.030^{* * *}$ \\
\hline Partisan orientation toward the winners & - & - & - & - & - & - \\
\hline Partisan attachment & $0.033^{* * * *}$ & $0.019^{* *}$ & $0.029^{* * *}$ & $0.029^{* * *}$ & $0.029^{* * *}$ & $0.029^{* * *}$ \\
\hline Level-2 variable & - & - & $-0.002^{*}$ & - & - & $0.147^{*}$ \\
\hline \multicolumn{7}{|l|}{ III. Rationality } \\
\hline Accountability & $0.059^{* * *}$ & $0.053^{* * *}$ & $0.058^{* * *}$ & $0.058^{* * *}$ & $0.058^{* * *}$ & $0.058^{* * *}$ \\
\hline Level-2 variable & - & - & - & - & - & - \\
\hline Representation system & - & - & - & - & - & - \\
\hline Representation parties or candidates & - & $0.020^{*}$ & $0.018^{* *}$ & $0.018^{* *}$ & $0.018^{* *}$ & $0.018^{* *}$ \\
\hline Level-2 variable & - & - & - & - & - & - \\
\hline Freedom & $0.075^{* * *}$ & $0.067^{* * *}$ & $0.084^{* * *}$ & $0.084^{* * *}$ & $0.084^{* * *}$ & $0.084^{* * *}$ \\
\hline Level-2 variable & - & - & - & $-0.012^{* * *}$ & $0.002^{*}$ & $0.298^{*}$ \\
\hline Corruption & - & - & - & - & - & - \\
\hline General performance & - & $0.049^{*}$ & $0.032^{* * *}$ & $0.031^{* * *}$ & $0.031^{* * *}$ & $0.032^{* * *}$ \\
\hline Level-2 variable & $0.028^{* * *}$ & - & - & $0.011^{*}$ & - & - \\
\hline Specific performance & - & - & - & - & - & - \\
\hline Satisfaction with democracy & $0.116^{* * *}$ & $0.165^{* * *}$ & $0.154^{* * *}$ & $0.154^{* * *}$ & $0.154^{* * *}$ & $0.154^{* * *}$ \\
\hline Level-2 variable & $0.040^{* * *}$ & - & - & - & - & - \\
\hline \multicolumn{7}{|l|}{ IV. Demographic controlled variables } \\
\hline Education & $0.041^{* * *}$ & $0.041^{* * *}$ & $0.041^{* * *}$ & $0.041^{* * *}$ & $0.041^{* * *}$ & $0.041^{* * *}$ \\
\hline Gender & $-0.017^{*}$ & $-0.017^{*}$ & $-0.017^{*}$ & $-0.017^{*}$ & $-0.017^{*}$ & $-0.017^{*}$ \\
\hline Age & $0.002^{* * *}$ & $0.002^{* * *}$ & $0.002^{* * *}$ & $0.002^{* * *}$ & $0.002^{* * *}$ & $0.002^{* * *}$ \\
\hline Constant & $3.357^{* * *}$ & $3.023^{* * *}$ & $3.261^{* * *}$ & $3.261^{* * *}$ & $3.259^{* * *}$ & $3.258^{* * *}$ \\
\hline Level-2 variable & $-0.102^{* * *}$ & $0.007^{* * *}$ & - & $-0.057^{* * *}$ & $0.013^{* * *}$ & $1.833^{* * *}$ \\
\hline Deviance & 96000 & 96038 & 96022 & 96004 & 96028 & 95944 \\
\hline$N$ & 53585 & 53585 & 53585 & 53585 & 53585 & 53585 \\
\hline
\end{tabular}


a stable cognitive value cultivated through the socialization process in the society where the political system is well-established as a democracy and the modernization has developed into an advanced level.

At last, we need to tease out the findings of crossover effects to explain what country-level factors account for the heterogeneity of individual-level findings cross-nationally. We start from the two macro predictors of the modernization/postmodernization perspective. As can be seen in Model VI, the level of GDP per capita has a crossover effect to strengthen the positive relationship between perceived level of individual freedom and belief in democracy. It means, as modernization proceeds, people will have even stronger faith in the superiority of democracy if they feel greater respect for individual freedom in society. The same conclusion can be found in Model VII if the GDI index replaces GDP per capita as the proxy variable of modernization with two more findings: people with a better economic condition tend to be less confident about the superiority of democracy as society becomes more modernized, but meanwhile those who hold a stronger partisan attachment have even more confidence in democracy. Overall, the crossover findings under the modernization/postmodernization framework indicate that the perceived level of individual freedom and partisan attachment are more and more influential in a modernizing social context. Nevertheless, people having a better socioeconomic status are usually less certain about the superiority of democracy.

If we shift our concern to the institutionalist macro predictors, we can find three crossover effects in Model VIII when a political system varies from parliamentarism to presidentialism as follows: people who express that they are satisfied with how democracy works and the general performance of the government tend to have a stronger belief in the superiority of democracy as the political system is more closer to presidentialism. At the same time, the positive relationship between income and belief in democracy is also even stronger. The latter finding is also corroborated when we use 'democratic lifespan' to replace 'type of government'. As can be seen in Model IX, we find the longer the country has been democratized, the positive relationship of income and belief in democracy is weakening since most of the established democracies with a longer democratic history adopt a parliamentary system, and it is exactly the opposite way to describe the same finding. To conclude what we found under the institutionalist framework, we found the belief in the superiority of democracy in the presidential system is more likely under the influence of performance-based factors such as satisfaction with democracy, government performance on general issues, and better personal economic conditions than in the parliamentary system.

With regard to the two rationalist macro predictors, three crossover effects can be concluded in Models X and XI which suggest that when the socioeconomic situation becomes worse in a society (reflected on a higher unemployment rate or lower economic growth rate), partisan attachment and government performance on general issues will become less influential to explain people's belief in the superiority of democracy; and the perceived level of individual freedom, on the other hand, plays a more important role in the explanation. The above findings suggest that psychological factors, such as partisan attachment, are losing leverage when the nation's economy is in a bad shape, but the connection between freedom and belief in democracy will be tightened once there is no strong economic performance to exploit as an excuse for the constraint of civil liberty. Also, as long as the government can maintain good socio-economic conditions to satisfy the public, people's belief in the superiority of democracy will be associated more with performance-based evaluation such as government performance on general issues instead of the values of civil liberty. Paradoxically, once the economic growth persists for a period of term, economic prosperity brings modernization into the equation and in turns increases the demand for civil liberty as well as its connection with belief in the superiority of democracy.

\section{Conclusion}

Democracy enjoys a significant base of popular support in the 41 country samples covered in CSES Module II. Nearly nine out of ten citizens (88.7\%) across all 41 countries say that they prefer democracy to other forms of government. ${ }^{18}$ While a higher level of support for democracy seems to be a defining feature of the established democracy, the emerging democracies including post-communist regimes also enjoy a solid base of pro-democracy sentiment. Our analysis also leads us to believe that the endurance of many emerging democracies is not under any immediate danger because popular belief in the superiority

\footnotetext{
$\overline{18}$ Among all of the applicable answers, $50.94 \%$ of people agree this statement and $37.74 \%$ strongly agree.
} 
of democracy is not susceptible to ups-and-downs of government performance or the short-term economic fluctuation.

However, there remains a marked gap between evaluations of the ideal and the practice of democracy. Only in 18 countries, did more than two-thirds of the citizens express satisfaction with the way democracy works. In 17 countries (about two-fifths of the 41 cases) less than $50 \%$ of the citizens are content with the practice of democracy. Our data provides solid evidence to support our initial claim that support for democracy as an ideal is conceptually different from satisfaction with the practice of democracy and that the generative mechanisms of the two variables on the one hand share some commonalities but are also sufficiently different. Furthermore, satisfaction with democratic practice remains relevant to the task of democratic consolidation as our analysis also indicates that satisfaction with democracy tends to buttress popular belief in the superiority of democracy.

Our analysis also demonstrates that all three theoretical perspectives are indispensable for a comprehensive understanding of the sources of democratic legitimacy for both established and emerging democracies. The transformative power identified by the modernization/ postmodernization perspective manifested itself largely through the impact of education and improvement of economic conditions on belief in democratic legitimacy. Our findings also buttress the institutionalist hypothesis that legitimacy is a function of cognitive mobilization through long-term exposure to democratic practices, participation in the democratic process and organized political affiliations. Our model has shown that both the length of the experience living under a democracy and level of political participation have an educational effect on citizens, adding to a sense of democratic legitimacy. However, most of the theoretical predictions based on a narrow conception of 'utility-maximization' turn out to be less relevant. Instead, our analysis shows that performance-based legitimacy is a function of a more diffuse basket of political goods including freedom, accountability and representativeness.

More specifically, we found that legitimacy based on a more diffuse basket of political goods and cognitive mobilization through participation in the democratic process remain robust after controlling for the effect of the length of a democracy's life span and level of economic development. People who participate more in the democratic process tend to develop a stronger belief in democracy's superiority and this is true for both old and young democracies, regardless of their difference in constitutional design, and for countries at very different stages of economic development. Also, people whose experience with the quality of governance is more positive also tend to develop a stronger belief in democracy's superiority and this is true for both old and young democracies, regardless of differences in constitutional design, and for countries at very different stages of economic development. Of course, we cannot be sure that the direction of causation necessarily runs from participatory experience to more positive orientations toward democracy. It might run the other way around, i.e., people who hold stronger belief in democracy's superiority are more motivated to take part in the electoral process. In reality, they probably come together and reinforce each other. ${ }^{19}$

Our findings also carry important policy implications. For emerging democracies, in order to move up the path toward more stable and consolidated democracy, their leaders need to place more emphasis on two relatively simpler tasks. The first objective is the involvement of citizens in the democratic process, not only through voting and electoral participation but also through organized affiliation with political parties. These activities will expand citizens' cognitive skills, accelerate the diffusion of democratic values and help citizens to develop stronger attachment to the political system.

The second objective is that governors must secure the rule of law, protect individual rights and freedom, and ensure that elections are meaningful and consequential. While these are issues commonly lumped today under the rubric of 'good governance' and associated with external pressures from the World Bank and IMF, they also appear to be very important to ordinary citizens at home. Put another way, the failure to achieve good democratic governance will imperil much more than access to foreign assistance, it will threaten the very prospects of popular support for democracy.

\footnotetext{
$\overline{19}$ While it is necessary to have more data points to investigate the causality of political participation and belief in democracy, we apply the method of two-stage least squares (2SLS) and find that the positive relationship stands firmly. Technically, our statistical findings presented at Table 2 are valid and not affected by the endogeneity problem of political participation and belief in democracy. However, unless we have panel data or better experimental design, the restriction of the cross-sectional data prevents us making a strong causal argument here. We acknowledge this limitation and caution the readers the possibility of causal reciprocity.
} 


\section{Appendix A. The construction of the variables}

\begin{tabular}{|c|c|c|}
\hline Variable name & Operationalization & Range \\
\hline Accountability & $\begin{array}{l}\text { Respondents' average of the answers to the questions 'Who is in power can make } \\
\text { difference' (B3013) and 'Who people vote for makes a difference' (B3014). The } \\
\text { former is recoded in the reversed order but the latter in the original order }\end{array}$ & 1 (lowest) to 5 (highest) \\
\hline Representation: system & $\begin{array}{l}\text { Respondents' answers to the question 'How well voter's views are represented in } \\
\text { elections' (B3022), recoding in the reversed order }\end{array}$ & 1 (lowest) to 4 (highest) \\
\hline $\begin{array}{l}\text { Representation: parties or } \\
\text { candidates }\end{array}$ & $\begin{array}{l}\text { The number of positive answers to the question 'Is there a party (B3023) or a } \\
\text { leader (B3025) that represents respondents' views?' }\end{array}$ & 3 (both), 2 (one), 1 (none) \\
\hline Freedom & $\begin{array}{l}\text { Respondents' answers to the questions 'How much respect is there for individual } \\
\text { freedom and human rights nowadays in your country' (B3043), recoding in } \\
\text { reversed order }\end{array}$ & 1 (lowest) to 4 (highest) \\
\hline Corruption & $\begin{array}{l}\text { Respondents' answers to the question 'How widespread do you think corruption } \\
\text { such as bribe taking is amongst politicians in your country' (B3044), recoding in } \\
\text { the reversed order }\end{array}$ & 1 (lowest) to 4 (highest) \\
\hline $\begin{array}{l}\text { Satisfaction with } \\
\text { democracy }\end{array}$ & $\begin{array}{l}\text { Respondents' answers to the question 'On the whole, are you very satisfied, or not } \\
\text { at all satisfied with the way democracy works in your country' (B3012), recoding } \\
\text { in reversed order }\end{array}$ & 1(lowest) to 4 (highest) \\
\hline General performance & $\begin{array}{l}\text { Respondents' answers to the question 'Now thinking about the performance in } \\
\text { [capital]/ president in general, how good or bad a job do you think the } \\
\text { government/ president in [capital] has done over the past several years?' (B3011), } \\
\text { recoding in a reversed order }\end{array}$ & 1 (lowest) to 4 (highest) \\
\hline Specific performance & $\begin{array}{l}\text { Respondents' answers to the question 'Thinking about the most important issue, } \\
\text { how good or bad a job do you think the government/ president in [capital] has } \\
\text { done over the past several years?' (B3010), recoding in reversed order }\end{array}$ & (lowest) to 4 (highest) \\
\hline Electoral participation & $\begin{array}{l}\text { The number of positive answers to the questions 'Whether the respondents voted } \\
\text { in the latest and previous elections' (both, only one, none, B3004_1 and B3016), } \\
\text { paired with the number of positive answers to the questions 'Whether the } \\
\text { respondents persuade others to vote for a candidate or whether the respondents } \\
\text { participate campaign activities' (both, only one, none, B3001_1, B3001_2). Taken } \\
\text { together, the result will be (number of voting, number of activities) }\end{array}$ & $\begin{array}{r}(2,2) \rightarrow 9 \\
(2,1) \rightarrow 8 \\
(2,0) \rightarrow 7 \\
(1,2) \rightarrow 6 \\
(1,1) \rightarrow 5 \\
(1,0) \rightarrow 4 \\
(0,2) \rightarrow 3 \\
(0,1) \rightarrow 2 \\
(0,0) \rightarrow 1\end{array}$ \\
\hline Non-electoral & The number of positive answers to the questions "Whether the respondents had & $0-3$ \\
\hline
\end{tabular}

participation

Partisan orientation toward the winner

Partisan attachment

Urban residence

Religious attendance

Income

Education

Gender

Age done the following things over the past five years: (1) contact politicians or officials, (2) protest or demonstration, (3) work with other to share concern' (B3042_1, B3042_2, B3042_3)

Whether the respondents voted for the wining camp in the last election? (Except Chile, Peru, Philippine, Russia, Taiwan (2004) and United States using B3005_1, Brazil and France using B3005_2, Albania using B3006_2, Japan using B3007_1, others apply B3006_1)

Respondents' answers to the question 'Do you feel very close to this [party/party block], somewhat close, or not very close?' Missing value means the respondents did not identify any party of party block they feel close and therefore is coded as zero (B3036)

Level of urbanization of respondent's residence. It is coded on a four-point Likert scale from 1 'the most rural' to 4 'the most urban' area (B2030)

Frequency of religious service attendance. It is coded on a six-point Likert scale from 1 'never' to 6 'once a week' (B2023)

Household income. It is coded from 1 'the lowest household income quintile' to 5 'the highest household income quintile' (B2020)

Level of education. In some cases, we found no ' 1 ' (none) and '2' (incomplete primary) answers, but in others we found there are ' 9 ' answers (more than basic university degree). To unify the scale, we combine ' 1 ', ' 2 ', ' 3 ' answers as ' 3 ' (primary completed or below), and ' 8 ' and ' 9 ' answers as ' 8 ' (university degree completed or above) (B2003)

Respondents' gender (B2002)

Respondents' age (B2001)

Range

1 (lowest) to 5 (highest)
1 (lowest) to 4 (highest)
3 (both), 2 (one), 1 (none)
1 (lowest) to 4 (highest)

1 (lowest) to 4 (highest) 
Appendix A (continued)

\begin{tabular}{lll}
\hline Variable name & Operationalization & Range \\
\hline $\begin{array}{l}\text { Belief in superiority of } \\
\text { democracy }\end{array}$ & $\begin{array}{l}\text { Respondents' answers to the question 'How strongly you agree or disagree with } \\
\text { the following statement: 'Democracy may have problems but it's better than any } \\
\text { other form of government'.' (B3015), recoding in reversed order } \\
\text { Type of government } \\
\text { Whether the country's political system is closer to the parliamentary system } \\
\text { (coded as 0) or the presidential system (coded as 3) }\end{array}$ & $0-3$ \\
Democratic lifespan & $\begin{array}{l}\text { How long the country has been democratized since 1945? The definition of } \\
\text { democracy is the polity score of } 6 \text { or above. The data come from POLITY IV }\end{array}$ & $3-60$ \\
Unemployment & $\begin{array}{l}\text { The average unemployment rate of the last four years from World Development } \\
\text { Indicators } \\
\text { The average GDP per capita growth rate of the last four years from World }\end{array}$ & $-0.48-7.01$ \\
Growth & $\begin{array}{l}\text { Development Indicators } \\
\text { The average GDP per capita (purchasing power parity, current international \$) of } \\
\text { the last four years from CIA World Factbook, except Taiwan using its official }\end{array}$ & $1798-37189$ \\
statistics & $\begin{array}{l}\text { The average gender development indicators of the last four years from Human } \\
\text { Development Report, except Taiwan using its official statistics to estimate }\end{array}$ & $0.701-0.948$
\end{tabular}

Note: There are some changes in the wording of the questions above for presentation purposes. The exact wording is available in the CSES questionnaire with reference to the ID numbers in parentheses.

\section{References}

Adcock, R., Collier, D., 2001. Measurement validity: a shared standard for qualitative and quantitative research. American Political Science Review 95 (3), 529-546.

Almond, G.A., Verba, S., 1963. The Civic Culture: Political Attitudes and Democracy in Five Nations. Princeton University Press, Princeton, NJ.

Anderson, C.J., Blais, A., Bowler, S., Donovan, T., Listhaug, O., 2005. Losers' Consent: Elections and Democratic Legitimacy. Oxford University Press, New York.

Bishin, B.G., Barr, R.R., Lebo, M.J., 2006. The impact of economic versus institutional factors in elite evaluation of presidential progress toward democracy in Latin America. Comparative Political Studies 39 (10), 1194-1219.

Brady, H., Verba, S., Schlozman, K., 1995. Beyond SES: a resource model of political participation. American Political Science Review 89 (2), 271-294.

Bratton, M., Chang, E.C.C., 2006. State building and democratization in Sub-Saharan Africa: forwards, backwards, or together? Comparative Political Studies 39 (9), 1059-1083.

Bratton, M., Mattes, R., 2001. Support for democracy in Africa: intrinsic or instrumental? British Journal of Political Science 31 (3), 447-474.

Bratton, M., Mattes, R., 2003. Learning about democracy in Africa. Paper presented at the East Asia Barometer Conference, Taipei, 8-9 December.

Bratton, M., Mattes, R., Gyimah-Boadi, E., 2005. Public Opinion, Democracy and Market Reform in Africa. Cambridge University Press, New York.

Bratton, M., Alderfer, P., Bowser, G., Temba, J., 1999. The effects of civic education on political culture: evidence from Zambia. World Development 27 (5), 807-824.

Dalton, R.J., 1999. Political support in advanced industrial democracies. In: Norris, P. (Ed.), Critical Citizens: Global Support for Democratic Governance. Oxford University Press, New York.

Diamond, L., 1999. Developing Democracy Toward Consolidation. Johns Hopkins University, Baltimore, MD.
Diamond, L., Shin, D.C. (Eds.), 2000. Institutional Reform and Democratic Consolidation in Korea. The Hoover Institution Press, Washington, DC.

Easton, D., 1965. A Systems Analysis of Political Life. Wiley, New York.

Easton, D., 1975. A re-assessment of the concept of political support. British Journal of Political Science 5 (4), 435-457.

Evans, G., Whitefield, S., 1995. The politics and economics of democratic commitment: support for democracy in transition societies. British Journal of Political Science 25 (4), 485-514.

Finkel, S., 1987. The effects of participation on political efficacy and political support: evidence from a West German panel. Journal of Politics 49 (2), 441-464.

Finkel, S., Sabatini, C., Bevis, G., 2000. Civic education, civil society and political mistrust in a developing democracy: the case of the Dominican Republic. World Development 28 (11), 1851-1874.

Hall, P., Taylor, R., 1996. Political science and the three new institutionalisms. Political Studies 44 (5), 936-957.

Halperin, M., Siegle, J., Weinstein, M., 2004. The Democracy Advantage: How Democracies Promote Prosperity and Peace. Routledge, New York.

Heath, A., Fisher, S., Smith, S., 2005. The globalization of public opinion research. Annual Review of Political Science 8, 297-333.

Inglehart, R., 1977. The Silent Revolution: Changing Values and Political Styles among Western Publics. Princeton University Press, Princeton, NJ.

Inglehart, R., 1997. Modernization and Postmodernization: Cultural, Economic and Political Change in 43 Societies. Princeton University Press, Princeton, NJ.

Inglehart, R., 1999. Postmodernization erodes respect for authority, but increases support for democracy. In: Norris, P. (Ed.), Critical Citizens: Global Support for Democratic Governance. Oxford University Press, Oxford.

Inkeles, A., Smith, D., 1974. Becoming Modern. Cambridge University Press, Cambridge.

Kitschelt, H., 1992. The formation of party systems in East Central Europe. Politics and Society 20 (1), 7-50.

Klingemann, H.-D., 1999. Mapping political support in the 1990s: a global analysis. In: Norris, P. (Ed.), Critical Citizens: Global 
Support for Democratic Governance. Oxford University Press, Oxford.

Linde, J., Ekman, J., 2003. Satisfaction with democracy: a note on a frequently used indicator in comparative politics. European Journal of Political Research 42 (3), 391-408.

Linz, J.J., Stepan, A., 1996. Problems of Democratic Transition and Consolidation: Southern Europe, South America, and Post-Communist Europe. Johns Hopkins University Press, Baltimore, MD.

Linz, J.J., Valenzuela, A., 1994. The Failure of Presidential Democracy. Johns Hopkins University Press, Baltimore, MD.

Mainwaring, S., 1993. Presidentialism, multipartism, and democracy: the difficult combination. Comparative Political Studies 26 (2), 198-228.

Mainwaring, S., Shugart, M.J., 1997. Juan Linz, presidentialism, and democracy: a critical appraisal. Comparative Politics 29 (4), 449-471.

McDonough, P., Shin, D.C., Moisés, J.Á., 1998. Democratization and participation: comparing Spain, Brazil, and Korea. Journal of Politics 60 (4), 919-953.

Mishler, W., Rose, R., 2005. What are the political consequences of trust? a test of cultural and institutional theories in Russia. Comparative Political Studies 38 (9), 1050-1078.

Morlino, L., Montero, J.R., 1995. Legitimacy and democracy in southern Europe. In: Gunther, R., Diamandouros, P.N., Puhle, H.-J. (Eds.), The Politics of Democratic Consolidation: Southern Europe in Comparative Perspective. The Johns Hopkins University Press, Baltimore, MD.

Muller, E., Seligson, M., 1994. Civic culture and democracy: the question of causal relationships. American Political Science Review 88 (3), 635-652.

Nie, N., Powell, G.B., Prewitt, K., 1969. Social structure and political participation. American Political Science Review 63 (2-3), 361-378.

Norris, P., 1999a. Introduction: the growth of critical citizens? In: Norris, P. (Ed.), Critical Citizens: Global Support for Democratic Governance. Oxford University Press, Oxford.

Norris, P. (Ed.), 1999b. Critical Citizens: Support for Democratic Governance. Oxford University Press, Oxford.

Power, T.J., Gasiorowski, M.J., 1997. institutional design and democratic consolidation in the third world. Comparative Political Studies 30 (2), 123-155.

Przeworski, A., 1991. Democracy and the Market: Political and Economic Reform in Eastern Europe and Latin American. Cambridge University Press, Cambridge.

Przeworski, A., Alvarez, M., Cheibub, J., Limongi, F., 1996. What makes democracies endure? Journal of Democracy 7 (1), 39-55.
Przeworski, A., Alvarez, M., Cheibub, J., Limongi, F., 2000. Democracy and Development: Political Institutions and Well-being in the World, 1950-1990. Cambridge University Press, Cambridge.

Putnam, R.D., 1993. Making Democracy Work: Civic Tradition in Modern Italy. Princeton University Press, Princeton, NJ.

Putnam, R., Pharr, S., 2000. Disaffected Democracies: What's Troubling the Trilateral Countries? Princeton University Press, Princeton, NJ.

Pye, L., 1990. Political science and the crisis of authoritarianism. American Political Science Review 84 (1), 3-19.

Rogowski, R., 1974. Rational Legitimacy: A Theory of Political Support. Princeton University Press, Princeton, NJ.

Rose, R., Mishler, W., 2003. Trust in Institutions. Paper presented at the East Asia Barometer Conference, Taipei, 8-9 December.

Rose, R., Mishler, W., Haerpfer, C., 1998. Democracy and Its Alternatives: Understanding Post-Communist Societies. The Johns Hopkins University, Baltimore, MD.

Ross, M., 2006. Is democracy good for the poor? American Journal of Political Science 50 (4), 860-874.

Sartori, G., 1976. Parties and Party Systems: A Framework for Analysis. Cambridge University Press, New York.

Schmitter, P., 1994. Dangers and dilemma of democracy. Journal of Democracy 5 (2), 57-74.

Shin, D.C., 1999. Mass Politics and Culture in Democratizing Korea. Cambridge University Press, New York.

Shin, D.C., Wells, J., 2005. Is democracy the only game in town? Journal of Democracy 16 (2), 88-101.

Shugart, M., Carey, J., 1992. Presidents and Assemblies: Constitutional Design and Electoral Dynamics. Cambridge University Press, New York.

Steinmo, S., Thelen, K., Longstreth, F. (Eds.), 1992. Structuring Politics: Historical Institutionalism in Comparative Analysis. Cambridge University Press, New York.

Stepan, A., Skach, C., 1993. Constitutional frameworks and democratic consolidation: parliamentarism versus presidentialism. World Politics 46 (1), 1-22.

Waldron-Moore, P., 1999. Eastern Europe at the crossroads of democratic transition: evaluating support for democratic institutions, satisfaction with democratic government, and consolidation of democratic regimes. Comparative Political Studies 32 (1), 32-62.

Weatherford, M.S., 1992. Measuring political legitimacy. American Political Science Review 86 (1), 149-166.

Whitefield, S., Evans, G., 1999. Political culture versus rational choice: explaining responses to transition in the Czech Republic and Slovakia. British Journal of Political Science 29 (1), 129-155. 